\title{
ENVIRONMENTAL (LOCAL AND GLOBAL IMPACT) AND ENERGY ISSUES ON SUGARCANE EXPANSION AND LAND OCCUPATION IN THE SÃO PAULO STATE
}

\author{
Evaristo Eduardo de Miranda
}

\section{INTRODUCTION}

Agribusiness land management is in the current agenda. All scientific, social, economic, and environmental matters related to expanding ethanol production in the São Paulo state border on land issues. For Brazilian society and abroad, such issues linked to the agricultural use of the land dominate the debate on the expansion of agro-energy and the production of biofuels. Scientific knowledge is yet insufficient due to the considerable time-space dynamics of sugarcane in the São Paulo state, and the diversity of existing agro-environmental situations. Among the issues connected to the sugarcane territorial expansion, there are the following:

- What are the impacts of the sugarcane space-time dynamics on the overall agricultural production in the São Paulo state?

- Does sugarcane expansion induce a reduction in food (grain or meat) producing areas?

- What are the impacts of this sugarcane dynamics on areas with natural vegetation? Does it favor or reduce them?

- Could change in the sugarcane production systems technology profile (elimination of burning, innovative waste management, electric power co-generation etc.) lead to a retraction in sugarcane areas in certain territorial circumstances?

The results from some studies on the timespace dynamics of land occupation and use in the São Paulo state have brought some relevant information; yet, they are still insufficient to span the whole breadth of this issue and its resulting impacts. However, focusing research only in sugarcane areas land use monitoring is not enough. Research should cover all types and classes of land use. To monitor land occupation and use, and its time-space dynamics, emphasizing sugarcane, research has to develop and use methodological tools based on geographic information systems, remote sensing and modeling.

This chapter, based on research of the expansion of sugarcane land in the Northeastern region of the São Paulo state, provides pointers on the subjects, methods, and scientific procedures to be developed mostly to supply the need for knowledge in this process' dynamics, capable of supporting agricultural land management and investments in infrastructure. The text also points out the most urgent research results, which public or private policy decision-makers need to bestow improved sustainability to the land ordinance of the São Paulo state, due to the expansion of agro-energy.

\section{A HISTORIC SUMMARY OF SUGARCANE AND LAND USAGE}

Initially, São Paulo lost its importance in this scenario. In 1590, there were six sugarcane mills in Rio de Janeiro. In 1600, sugarcane occupied some 6,600 hectares. In 1728, the number of sugarcane mills rose to 32 , and, in 1797 , they were 120 . Rio de Janeiro city toponymy still recalls this cycle, 
with places named Engenho Novo, Engenho de Dentro, Usina da Tijuca, Engenho Velho, Engenho da Rainha, Engenho da Pedra etc.; "Engenho" being the Portuguese word for "sugar mill". Brazil increased its exports, and in 1700 it shipped 19,000 tons per year; after some oscillations, this figure reached 24,000 tons in 1800 .

Circumstantiated scientific studies observed that, during the Portuguese domain period, the average cultivated area per year was 9,000 hectares, reaching a maximum of 16,000 hectares at the outset of the Empire. In a maximalist scenario, the total deforestation for sugar production over more than 220 years, at the time of Independence, was close to 140,000 hectares. If compared to the extension of the Atlantic Forest, deforestation caused by sugarcane during a period of over 200 years by its population, can be considered negligible ${ }^{1}$. Currently, in one year alone, Brazil produces much more sugarcane than it did throughout the whole period of colonization by the Portuguese ${ }^{2}$.

After the introduction of the Alcohol Fuel program in the 1970s, sugarcane gained new territorial dynamics in São Paulo, expanding its area in both traditional cultivation areas in, for example, Piracicaba and Ribeirão Preto, as well as in regions further West, such as the Assis area, occupying mostly cerrado lands dedicated to animal breeding, and seasonal cultures, having varied impacts ${ }^{3}$.

In the 1970s, a crew from Terrafoto S.A., a land study and airborne survey connected to the São Paulo state government, taking into account restrictions of remote probing and geographic information systems existing at that time, made breakthrough surveys on this issue. They mapped land usage in a great deal of the São Paulo state, emphasizing sugarcane on two dates: early 1960s,

\footnotetext{
1 CASTRO, C. F. A. Gestão florestal no Brasil Colônia. Brasília: UnB, 2002.

2 In 2008, sugarcane production reached almost 500 million tons in the São Paulo state.

3 PAMPLONA, C. Proalcool: impacto em termos técnicos econômicos e sociais do programa no Brasil. Belo Horizonte: SOPRAL, 1984. 93p.
}

based on air photos and later, the updated situation in the late 1970s, based on different surveys ${ }^{4}$. When Terrafoto S.A. was privatized in $1980^{5}$, this work was discontinued, as it was interesting for public policies, but not for air survey private activities. Public institutions did not require such services either. Nowadays, access to this data is difficult for reasons linked to Terrafoto's records destination, and the very geo-processing technology employed at that time.

Nowadays, the sugarcane industry maintains, by means of União da Indústria de Cana-de-Açucar - Unica (Sugarcane Industry Union), keeps an exclusive monitoring of areas planted with sugarcane (Canasat) in cooperation with Funcate and Inpe ${ }^{6}$. Figures from the 2007-2008 harvest season indicate the constantly growing area and sugarcane harvest in the Center-South region, which represents $86 \%$ of the domestic production. There was 414 million tons of sugarcane, compared to 366 million in the previous harvest season: a 13\% growth. It is estimated that 29 new mills will start operating in the region, being 13 of them in the São Paulo state, which implies another increase in cultivated area and production, around $10 \%{ }^{7}$.

\section{THE CASE OF THE NORTHEASTERN REGION OF SÃO PAULO STATE}

The Northeastern region of the São Paulo state is an example of Brazilian agribusiness territorial development, being the national productivity leader in the major agricultural segments, mostly based in sugarcane expansion. Its Gross Internal Product, above USD 25 billion, is higher than Uru-

\footnotetext{
4 SERRA FILHO R.; CAVALLI A. C.; GUILLAUMON JR. Levantamento da cobertura natural e do reflorestamento no Estado de São Paulo - Boletim Técnico do Instituto Florestal, 1974.

5 Available at: <http://www.al.sp.gov.br/staticfi le/integra_ ddilei/decreto/1980/decreto\%20n.15.471,\%20de\%2007.08.1 980.htm>.

6 Available at: <http://www.dsr.inpe.br/canasat/>.

7 Produção em crescimento. Agroanalysis, São Paulo, FGV, vol. 28, abril 2008.
} 


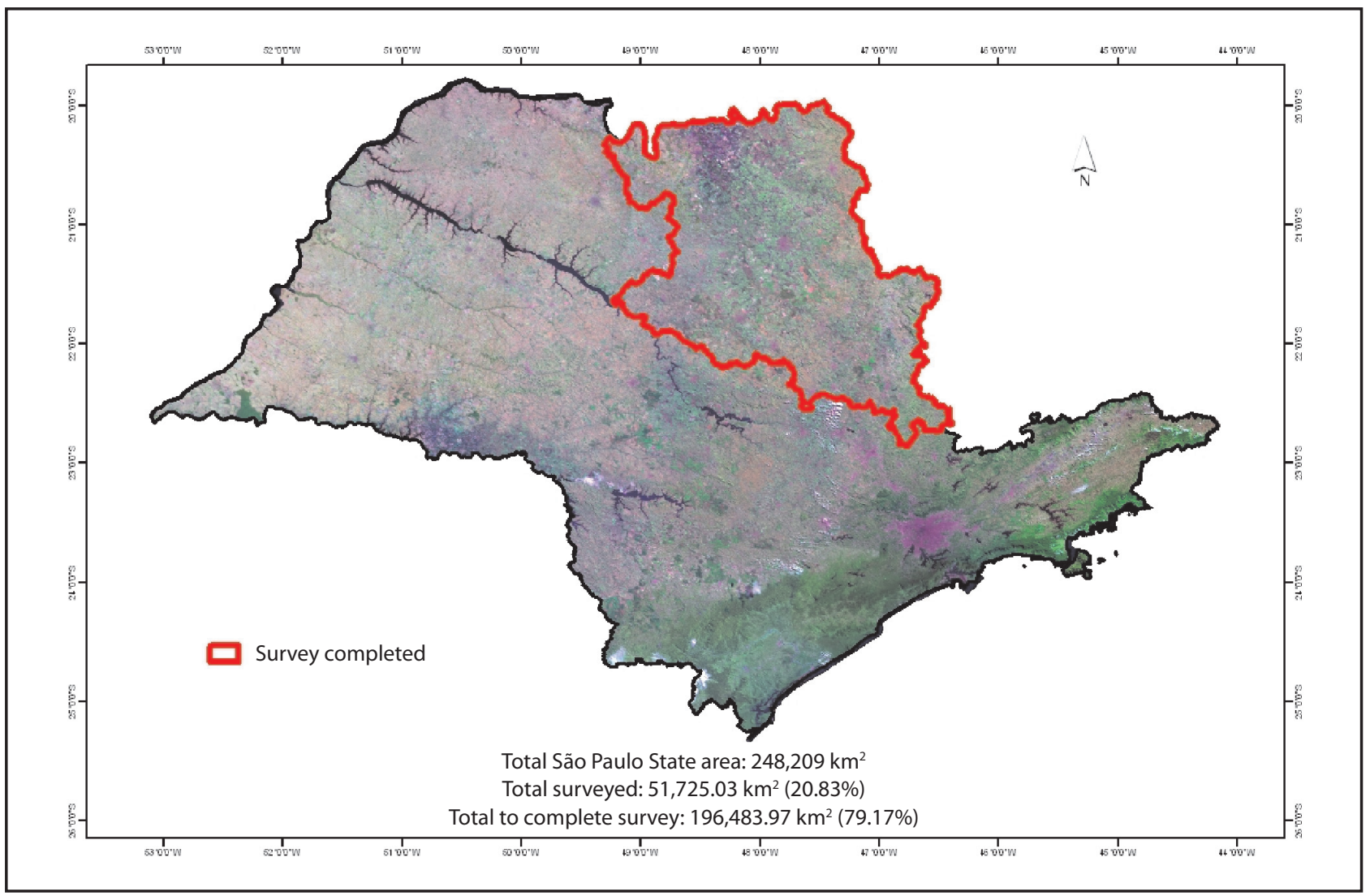

FIGURE 1 Location of the study area in the São Paulo State.

guay's, and its per capita income is twice as much as Argentina's ${ }^{8}$.

A study of land usage and land management carried out by Embrapa Monitoramento por Satélite (satellite monitoring) covered 125 municipalities, approximately $51,725 \mathrm{~km}^{2}$, and $20.83 \%$ of the São Paulo state (Figure 1) ${ }^{9}$. Town, regional and trade leaderships seek participation in public policies for land, and need updated information on agricultural land usage and spatial dynamics coverage, which, in partnership with the project " $D i$ agnóstico Ambiental da Agricultura no Estado de São Paulo: bases para um desenvolvimento rural sustentável - Ecoagril Fapesp" ${ }^{10}$ and the

8 ELIAS, D. Globalização e agricultura: a região de Ribeirão Preto/SP. São Paulo: Edusp, 2003.

9 Available at: <http://www.cnpm.embrapa.br/publica/down - load/newsdownload/artigos_resumos\%20anais\%20eventos/ apc_44cbesrsober06_gestaoterrnesp_mir.pdf>.

${ }^{10}$ Available at: <http://ecoagri.cnptia.embrapa.br/indexphp>. support of Abag-RP ${ }^{11}$ (Brazilian Agribusiness Association of the Ribeirão Preto Area), structured an agribusiness land management system for this region.

Materials and key data used as grounds for usage mapping and land coverage work were images from satellites LANDSAT 7-ETM+, LANDSAT 5-TM, and the vector file with the municipal grid from Instituto Brasileiro de Geografia e Estatística - IBGE (Brazilian Institute of Geography and Statistics) (1999). Ortho-rectified aerial photos, on a 1:30,000 scale from 2001, and images from the satellites Cbers and Spot were used as support information. The main software packages used were Erdas Imagine and ArcGIS.

The land use and coverage map was initially obtained for 2003. Image interpretation was done on a 1:180,000 scale for representation in 1:250,000, considering 25 ha as the smallest

${ }^{11}$ Available at: <http://www.abagrp.com.br/>. 
charted element. The same process was used for the 1988 mapping. The resulting key includes the following land usage and coverage categories: sugarcane, fruit, coffee, rubber, yearly cultures (corn, soy, peanuts, beans, rice), yearly cultures on irrigation pivots, pastures, natural and riparian vegetation remnants, urban areas, mining areas, and other uses/coverage (open soil, exposed rock etc.), and water bodies (lakes, rivers, dams etc.) ${ }^{12}$.

Tables and charts on the land usage and coverage dynamics were obtained by crossing (intercept) of the 1998 and 2003 usage and coverage maps using geo-processing techniques. Data obtained were entered on a Geographic Information System, together with other information plans, such as: municipal division, hydrography, topography, basins etc.

A database containing agronomic, social, economic, and environmental data was built for each type of vegetation coverage mapped in the region from various information sources, and field surveys with farmers and technical support agencies. Each variable in this database may be spatialized within the region, and was used to structure other composite variables.

\section{THE REGIONAL AGRICULTURAL DYNAMICS BETWEEN 1988 AND 2003}

Land usage and coverage maps, obtained for 1988 and 2002/2003 are represented in a summarized form in Figures 2 and 3. The original maps are in a 1:250,000 scale and complete data may be found at CRISCUOLO et al., $2006^{13}$.

From the intercepts by geo-processing of the maps obtained for each period it was possible to analyze the land usage and coverage dynamics for each category. Table 1 presents, in a cross-referenced way and summarized by usage and coverage

${ }^{12}$ DI GREGÓRIO, A.; JANSEN, L. J. M. Land Cover Classification System (LCCS): Classification Concepts and User Manual. Rome: Food and agriculture organization of the United Nations, 2000. 179p.

${ }^{13}$ CRISCUOLO C.; QUARTAROLI, C. F.; MIRANDA, E. E.; GUIMARÃES, M. Dinâmica de uso e cobertura das terras na região nordeste do Estado de São Paulo. Campinas: Embrapa Monitoramento por Satélite, 2006. 70 p., il. (Documentos, 46). category, the quantitative changes occurred in the area studied between 1988 and 2002/2003.

Table 1 summarizes each category's summarized quantitative data for each category mapped for 1988 and 2003.

From the intercepts by geo-processing of the maps obtained for each period it was possible to analyze the land usage and coverage dynamics for each category. Table 2 presents, in a cross-referenced way and summarized by usage and coverage category, the quantitative changes occurred in the area studied between 1988 and 2003.

\section{SUGARCANE RETRACTION, PERMANENCE, AND EXPANSION}

After the land usage and coverage maps in 1988 and 2003 were concluded, it was possible to make space and time analysis of the dynamics in the past 15 years, especially in the rural area. The time analysis of land usage and coverage pointed out the expansion of sugarcane, mostly over grazing lands and yearly cultures, like in other studies ${ }^{14}$.

In 1988, sugarcane occupied 1,085,668 ha of the Northeastern region of the São Paulo state (21\%), being concentrated around the central axis of the area studied, including the whole municipality of Ribeirão Preto as core area. In 2003, the area covered with sugarcane was 2,293,301 ha, which represented a leap from $21 \%$ to $44 \%$ of the area studied (Table 1).

One of the interesting features of a land management tool for agribusiness, based on the spatial knowledge of land usage and coverage, is in its capability of considering what took place in every hectare of sugarcane between 1988 and 2003. The figure shows sugarcane retraction, permanence, and expansion areas. Digital charting treatment of this information allows the quantification of sugarcane permanence area between the two periods: 989,523 ha, i.e., from the present 2,293,301 ha,

${ }^{14}$ COElHO S. T.; LORA, B. A.; MONTEIRO, M. B. C. A. A expansão da cultura canavieira no Estado de São Paulo. USP. São Paulo: Cenbio. Available at: <http://www.cenbio.org.br/pt/ downloads/papers/expcana.pdf $>$. 


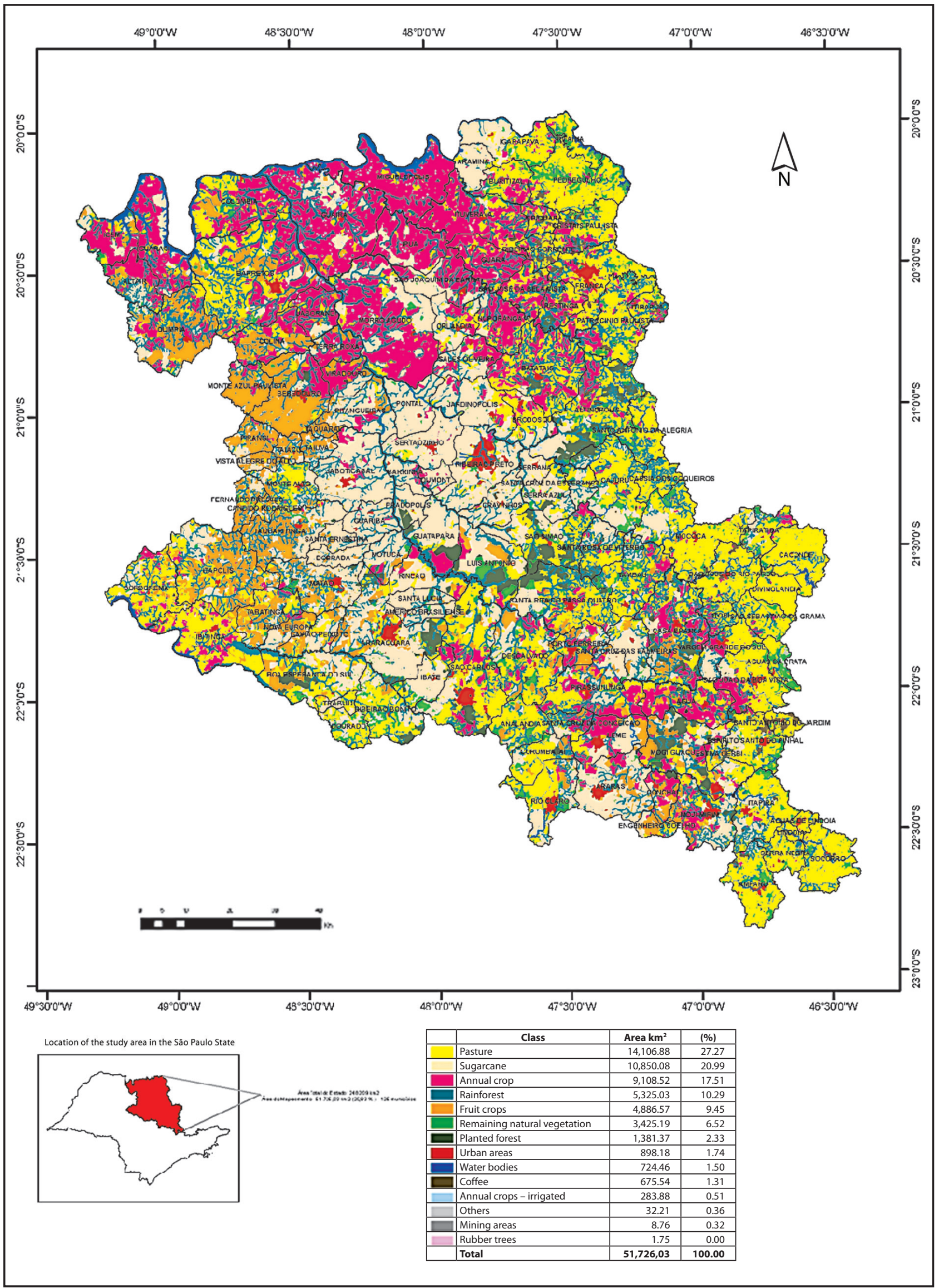

FIGURE 2 Synthetic map of land usage and coverage in 1988. 


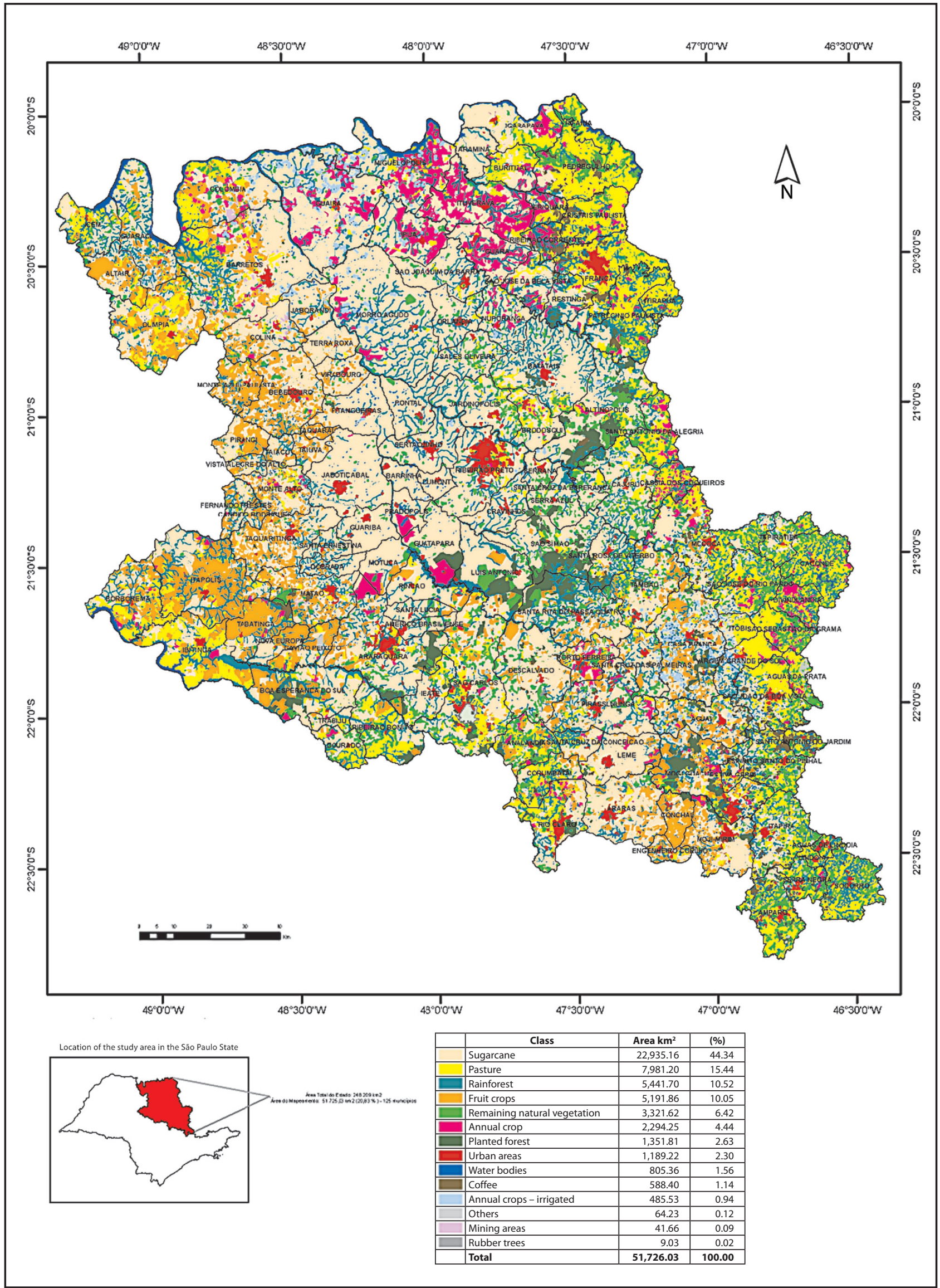

FIGURE 3 Synthetic map of land usage and coverage in 2002/2003. 
TABLE 1 Quantificaion of land coverage in 1988 and 2003.

\begin{tabular}{|c|c|c|c|c|}
\hline \multirow[b]{2}{*}{ Category/class } & \multicolumn{2}{|c|}{1988} & \multicolumn{2}{|c|}{$2002 / 2003$} \\
\hline & $4,126,120$ & 79.77 & $4,089,374$ & 79.06 \\
\hline Pasture & $1,410,688$ & 27.27 & 798,956 & 15.45 \\
\hline Sugarcane & $1,085,668$ & 20.99 & $2,293,301$ & 44.34 \\
\hline Annual crop & 910,852 & 17.61 & 229,455 & 4.44 \\
\hline Fruit crop & 488,657 & 9.45 & 519,739 & 10.05 \\
\hline Planted forest & 136,137 & 2.63 & 135,783 & 2.63 \\
\hline Annual crop - irrigated & 26,388 & 0.51 & 48,566 & 0.94 \\
\hline Rubber trees & 175 & 0.00 & 4,761 & 0.09 \\
\hline Coffee & 67,554 & 1.31 & 58,823 & 1.14 \\
\hline Antropic areas & 93,915 & 1.82 & 126,217 & 2.44 \\
\hline Urban areas & 89,818 & 1.74 & 118,898 & 2.30 \\
\hline Others & 3,221 & 0.006 & 6,416 & 0.12 \\
\hline Mining areas & 876 & 0.02 & 903 & 0.02 \\
\hline Natural vegetation & 875,022 & 16.92 & 876,431 & 16.94 \\
\hline Rainforest & 532,503 & 10.29 & 544,091 & 10.52 \\
\hline Remaining natural vegetation & 342,519 & 6.62 & 332,340 & 6.43 \\
\hline Water bodies & 77,446 & 1.50 & 80,480 & 1.56 \\
\hline Water bodies & 77,446 & 1.50 & 80,480 & 1.56 \\
\hline Total & $5,172,503$ & 100.00 & $5,172,503$ & 100.00 \\
\hline
\end{tabular}

TABLE 2 Land usage and coverage dynamics in the Northeastern region of the São Paulo state, by analysis categories (numbers in ha).

\begin{tabular}{|c|c|c|c|c|c|c|}
\hline & & \multicolumn{4}{|c|}{$2002 / 2003$} & \multirow[b]{2}{*}{ Total (1988) } \\
\hline & & $\begin{array}{c}\text { Agriculture } \\
\text { and livestock }\end{array}$ & $\begin{array}{c}\text { Natural } \\
\text { vegetation }\end{array}$ & Antropic areas & Water bodies & \\
\hline \multirow{4}{*}{$\begin{array}{l}\infty \\
\infty \\
a \\
\sigma\end{array}$} & $\begin{array}{l}\text { Agriculture and } \\
\text { livestock }\end{array}$ & $4,015,964$ & 76,092 & 30,701 & 3,363 & $4,126,119$ \\
\hline & $\begin{array}{l}\text { Natural } \\
\text { vegetation }\end{array}$ & 70,745 & 795,125 & 2,032 & 7,121 & 875,023 \\
\hline & Antropic areas & 527 & 100 & 93,195 & 94 & 93,915 \\
\hline & Water bodies & 2,139 & 5,114 & 290 & 69,902 & 77,446 \\
\hline \multicolumn{2}{|c|}{ Total (2002/2003) } & $4,089,374$ & 876,431 & 126,217 & 80,480 & $5,172,503$ \\
\hline
\end{tabular}




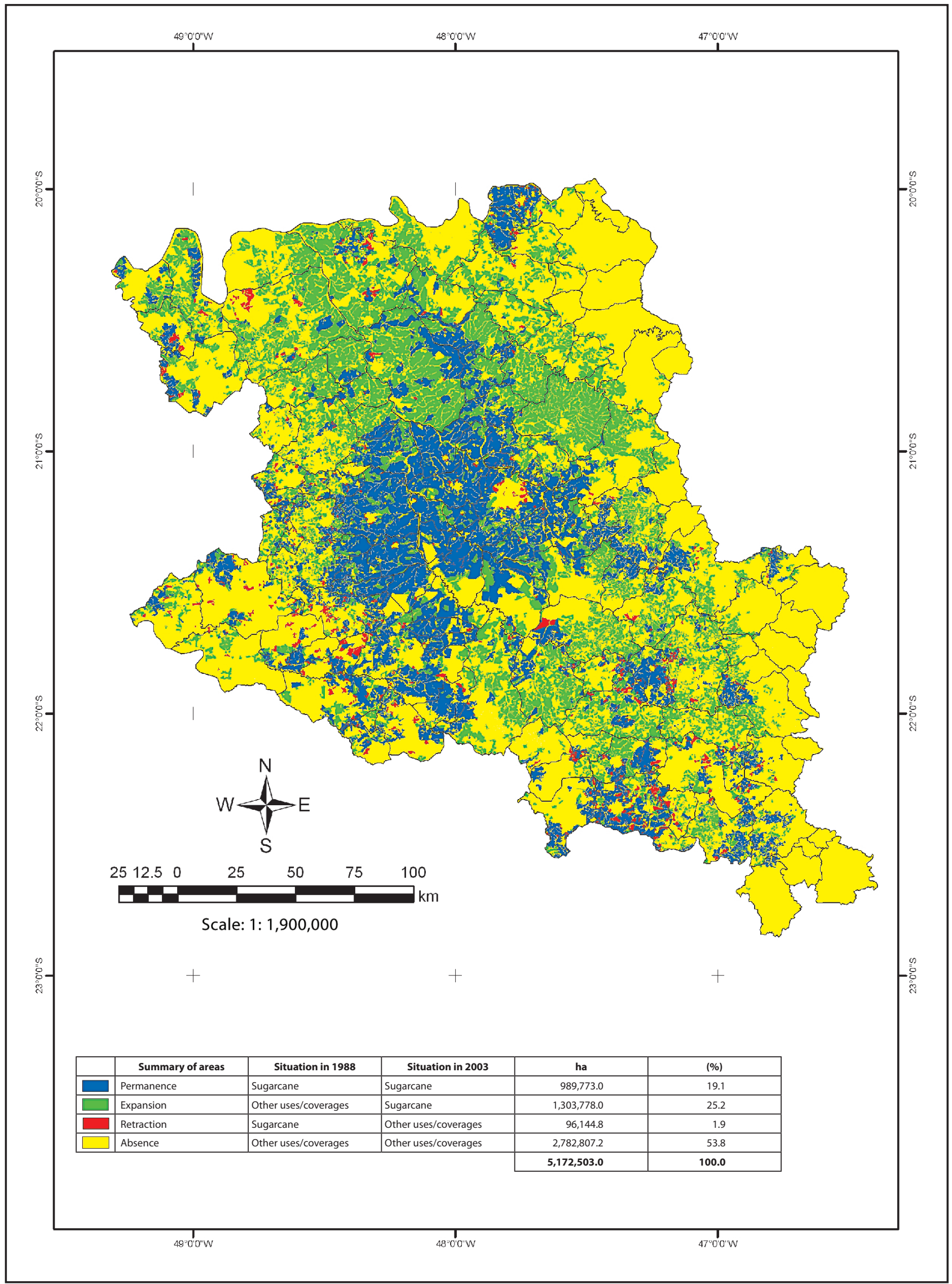

FIGURE 4 Sugarcane permanence, expansion, retraction, and absence areas in the Northeastern region of the São Paulo state, obtained from land usage and coverage mapping in 1988 and 2003. 
only 989,523 ha were sugarcane in 1988. This indicates that in other areas there was either retraction or expansion of the culture, as shown on Figure 4.

Retraction of this activity took place on 96,145 ha, and the land management system allows to identify major cultures that replaced sugarcane in these places: 40,113 ha were occupied with fruit; 14,729 ha with grazing land; and 11,058 ha with yearly cultures. The remaining area, around 30,254 ha, was occupied by various cultures (coffee, rubber, and silviculture), by restoring riparian forests, and other uses (dams, urbanization etc.).

The sugarcane expansion area was 1,303,778 ha, mostly over 596,345 ha of yearly cultures, 474,743 ha of grazing lands; and 157,680 ha of fruit cultures. Knowing the socio-economic indicators of each one of these cultures, it is possible to assess the impacts of this land usage and coverage dynamics, in terms of employment, income and levied taxes.

\section{EVALUATION OF SOCIAL, ECONOMICAL, AND TERRITORIAL IMPACTS}

This agribusiness land management system allowed following the land usage and coverage dynamics in each section of that region. Contrary to census and numerical data, it is possible to know, in a circumstantiated manner, which cultures were replaced in the sugarcane expansion, or which replaced sugarcane where there was a retraction. The system calculated this dynamic for each category and land usage class. Having such information for the whole São Paulo state would be highly relevant to monitor what is actually taking place, and its environmental and socio-economic impacts.

To illustrate, here are the evolutions of some socio-economical indicators, such as direct employment, though the land management system also has data on indirect, induced, and total jobs in each of the productive chains. Likewise, only direct taxes levied will be presented to illustrate, though there is also information on indirect, induced, and total taxes in each of the Northeastern region of the São Paulo State productive chains. Figures for gross income are based on the best prices obtained in the region in 2003. Results obtained and commented are presented next.

\section{Gross income}

Culture replacements, both for sugarcane retraction and expansion, were duly computed, thanks to the land management system. In the case of areas where there was a retraction of sugarcane, being replaced by other cultures (78,333 ha), the current use generates about $\mathrm{R} \$ 223$ million in gross income, against a potential income - if sugarcane had been maintained in these places - of about $\mathrm{R} \$ 219$ million.

This represents a gain in gross income in these sugarcane retraction areas of about $\mathrm{R} \$ 34$ million. Agronomical and environmental reasons also explain such changes, and justify the rationale for this spatial evolution.

In the case of sugarcane expansion, this additional area $(1,266,681 \mathrm{ha})$ generates a potential gross income of about $\mathrm{R} \$ 3.5$ billion against a theoretical gross income - had the previous usages been maintained - of around $\mathrm{R} \$ 2.1$ billion. This represents a gain, in terms of gross income, of about $\mathrm{R} \$ 1.5$ billion, i.e, an average gain of $\mathrm{R} \$ 1,161 /$ ha in comparison to the other uses.

Considering the positive and negative compensations in terms of gross income in the area currently occupied by sugarcane in the Northeastern region of the São Paulo state, there was a gain of around $\mathrm{R} \$ 1.5$ billion.

\section{Direct employment}

In the case of areas where there was a retraction of sugarcane, and its replacement with other cultures (78,333 ha), the land management system estimated that the current use of the land generates around 10,825 direct jobs, against a potential of - if the sugarcane had been maintained in these places - of about 5,483. This represents a gain in direct jobs, in these areas of sugarcane retraction, of around 5,342. Job qualification, the resulting income profile etc. are not the same, but the data indicates such evolution. 
In the case of sugarcane expansion, this additional 1,266,681 ha area generates a direct jobs potential of about 88,668 against the theoretical - if the previous usages had been maintained - of around 115,484 . This represents a loss in direct jobs of about 26,817 . Globally, with this whole picture of change in land usage, there was a net loss of 21,475 jobs.

On the other hand, studies by Federação das Indústrias do Estado de São Paulo - Fiesp (São Paulo State Federation of Industries) show that the sugar-alcohol industry sector was responsible until April - for about 80\% of the vacancies opened by the São Paulo state industry in 2008. From the 127,000 vacancies opened in the first four months, slightly over 94,000 of them were in sugarcane mills or plantations ${ }^{15}$.

\section{Direct taxes}

In the case of areas where there was a retraction by sugarcane, and its replacement by other cultures (78,333 ha), the current land usage and coverage represent a total of about $\mathrm{R} \$ 6.7$ million in direct taxes, against a potential - if the sugarcane had been maintained there - of about $\mathrm{R} \$ 7.8$ million. This means a loss in direct tax revenue of around $\mathrm{R} \$ 1.2$ million.

In the case of sugarcane expansion, this additional area of 1,266,681 ha generates potential direct taxes of around $R \$ 127.5$ million against a theoretical direct levy - had the previous usages been maintained - of around $\mathrm{R} \$ 65.6$ million. This represents a gain in direct taxes levy of about $\mathrm{R} \$ 61.9$ million. Here too, as in the case of jobs, sugarcane favors local taxes, and not their concentration in remote agricultural products processing hubs. Overall, with this scenario of change in the usage of land, there was a net gain in taxes levied of around $\mathrm{R} \$ 60.7$ million.

\section{FINAL CONSIDERATIONS}

The sugarcane expansion, the land usage and occupation in the São Paulo state present

15 Available at: <http://www1.folha.uol.com.br/folha/dinheiro/ ult91u402320.shtml>. unprecedented dynamics ${ }^{16}$. The scientific, social, economic, and environmental themes linked to the expanded production of ethanol require inexistent or insufficient land information. Considering the weight of these land issues - for both Brazilian and international society - connected to the agricultural use of land, new methods and research should be driven to enlarge the actual knowledge on the space-time dynamics of agro-energy and fuel production in the São Paulo state.

This chapter, upon having dealt with this subject, introduced the example of a new agribusiness land management system, structured by Embrapa Monitoramento por Satélite (satellite monitoring) for 125 municipalities located in the Northeastern region of the São Paulo state, in partnership with several institutions, with support from Fapesp and Abag/RP (Brazilian Agribusiness Association of the Ribeirão Preto Area). From the methodological standpoint, the land management system articulated three modules: land use and coverage; agronomical, social, and economical database; and the geographic information system.

Land mapping, usage, and coverage are remarkable tools to follow land changes in agriculture, and their methods behoove improvements. The dynamics observed in the last 15 years in the Northeastern region continues to occur in the São Paulo state. Every agricultural year there are changes in the spatial division of activities, and the satellite images provide a systematic record of these realities. From the satellite images to the final cartographic product there is a whole series of data gathering and processing, both in laboratory and in the field, which requires new surveys and operational resources.

From the conceptual standpoint, technicians and researchers always keep a double denomination: land use and coverage, or land use and occupation. In practice, this poses an actual difficulty due to

${ }^{16}$ CAMARGO A. M. M. P. DE; CASER D. V.; CAMARGO F. P. DE; OLIVETTE M. P. DE A.; SACHS R. C. C.; TORQUATO S. A. Dinâmica e tendência da expansão da cana-de-açúcar sobre as demais atividades agropecuárias, Estado de São Paulo, 2001-2006. Informações Econômicas, vol. 33, n. 3, São Paulo: IEA, 2008. Available at: <(http://www.iea.sp.gov. br/out/publicar/ieant.php)>. 
farming systems' nature and dynamics. In the case of fruit production, for instance, land usage and occupation or coverage, are equivalent. In the case of sugarcane, this no longer happens. In a certain area, 1,000 ha may be covered or occupied by sugarcane; however, yearly a little less than $20 \%$ of this culture will be reformed, probably with yearly cultures (peanut, soy etc.). In other words, occupation is by sugarcane, but the use, in that year, will be by yearly cultures. Depending on the manager's objectives, cartographic data may be reclassified, getting closer to the use of the land, getting the information nearer the themes of production systems, technology levels, short-term fluctuations etc. However they may be reclassified towards the sense of land occupation, or coverage, reflecting more accurately the midrange issues, production structures, and the higher determinants of the agribusiness.

From this standpoint, considering sugarcane alone in terms of occupation or coverage, the area in the Northeastern region of the São Paulo state in 2003 was about $51 \%$. If the sugarcane plantation retrofit indexes are applied, this figure drops to $44 \%$, and a considerable part of this difference may be credited to yearly cultures. New research efforts should accurately evaluate the grain production actually occurring within sugarcane areas.

In all natural resources mapping, scale creates the phenomenon. Land usage and coverage mapping in a region will not provide the same qualitative and quantitative result if a different scale is used. The 1:250,000 scale has offered São Paulo state agribusiness managers an adequate compromise in terms of cost/benefit, between accuracy and the required speed in obtaining results for regional studies of this nature. However more and newer research studies may also deepen this dimension.

Finally, among the issues connected to sugarcane territory expansion, several questions trouble public policy makers, and various segments of our society await answers from research:
- What are the key changes in land use and occupation by water basins and governmental districts caused by sugarcane in the São Paulo state?

- What are the regions and towns in the São Paulo state that were most affected by the current sugarcane area expansion dynamics?

- What are the indirect impacts of this land occupation dynamics, and in the use of land in other regions in the São Paulo state that are unsuited for sugarcane?

- To what extent does sugarcane expansion compete with food production, and if so in what dimension, and in which towns and regions?

- What are the regions in the São Paulo state where sugarcane expansion competes with citrus cultures and energy forests?

- In which regions does sugarcane spacial dynamics lead to a reduction in the number of cattle?

- What has been the connection between reduced grazing lands and cattle head count?

- Does sugarcane expansion cause deforestation, thus compromising the preservation of natural vegetation, or does it favor - by exclusive mechanization of flat areas - the recovery of permanent preservation areas?

- What are the water basins most affected by sugarcane expansion, and what are the likely positive and negative impacts on water resources?

- What gains and threats do sugarcane expansion presents to the Guarani aquifer?

- What are the regions where sugarcane burning has had seen the greatest increase, decrease, or remained stable?

- To what extent can city and state laws favor or restrict agricultural land usage by sugarcane? 
